\title{
Investigations and Applications of Nanoperm-Type Soft Magnetic Materials
}

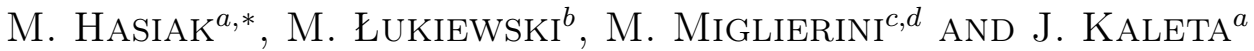 \\ ${ }^{a}$ Institute of Materials Science and Applied Mechanics, Wrocław University of Technology \\ M. Smoluchowskiego 25, 50-370 Wrocław, Poland \\ ${ }^{b}$ ELHAND Transformatory, PCK 22, 42-700 Lubliniec, Poland \\ ${ }^{c}$ Slovak University of Technology, Ilkovičova 3, 812-19 Bratislava, Slovakia \\ ${ }^{d}$ Centre for Nanomaterials Research, Palacky University \\ Šlechtitelů 11, 771-46 Olomouc, Czech Republic
}

\begin{abstract}
The microstructure and magnetic properties of $\mathrm{Fe}_{82} \mathrm{Zr}_{4} \mathrm{Nb}_{3} \mathrm{~B}_{10} \mathrm{Cu}_{1}, \mathrm{Fe}_{80} \mathrm{Zr}_{4} \mathrm{Mn}_{3} \mathrm{~B}_{12} \mathrm{Cu}_{1}$ and $\mathrm{Fe}_{80} \mathrm{Zr}_{4} \mathrm{Ti}_{3} \mathrm{Cu}_{1} \mathrm{~B}_{12}$ alloys were investigated. Using RALE software the basic parameters of transformers made from nanocrystalline alloys with about $25 \%$ and $50 \%$ of crystalline phase were calculated. The transformer made from $\mathrm{Fe}_{80} \mathrm{Zr}_{4} \mathrm{Ti}_{3} \mathrm{Cu}_{1} \mathrm{~B}_{12}$ alloys after annealing at $773 \mathrm{~K}$ for $1 \mathrm{~h}$ shows the lowest core losses and highest efficiency.
\end{abstract}

PACS numbers: 81.05.Kf, 81.07.Bc, 81.40.Rs, 85.70.Ay

\section{Introduction}

Nanocrystalline Nanoperm-type ( $\mathrm{Fe}-\mathrm{Zr}-\mathrm{B}-\mathrm{Cu})$ alloys are interesting as materials for magnetic cores because their good soft magnetic properties i.e. high susceptibility, low coercivity, low core losses and good frequency characteristics connected with high saturation induction [1]. These materials usually obtained from amorphous precursors by proper heat treatment can be also created in production process. It is well known that the magnetic properties of Nanoperm alloys strongly depend on the microstructure and chemical composition of precursor. Addition of such elements as $\mathrm{Nb}, \mathrm{Mn}$, Ti, Hf and other metalloid atoms to $\mathrm{Fe}-\mathrm{Zr}-\mathrm{B}-\mathrm{Cu}$ alloys during fabrication leads to changes of their soft magnetic properties [2].

The aim of this paper is to study the evolution of microstructure and magnetic properties of Nanoperm alloys as well as simulation of transformer parameters for design of toroidal cores in a flyback transformer.

\section{Experimental}

Ribbons of nominal composition of $\mathrm{Fe}_{82} \mathrm{Zr}_{4} \mathrm{Nb}_{3} \mathrm{~B}_{10} \mathrm{Cu}_{1}, \quad \mathrm{Fe}_{80} \mathrm{Zr}_{4} \mathrm{Mn}_{3} \mathrm{~B}_{12} \mathrm{Cu}_{1}$, and $\mathrm{Fe}_{80} \mathrm{Zr}_{4} \mathrm{Ti}_{3} \mathrm{Cu}_{1} \mathrm{~B}_{12}$ with a width of $2.2 \mathrm{~mm}$ and thickness of $0.02 \mathrm{~mm}$ were obtained by rapid quenching method on a single roller with the same rotation velocity. The

* corresponding author; e-mail: Mariusz.Hasiak@pwr.wroc.pl microstructure of the investigated samples was tested by X-ray diffractometry and the Mössbauer spectroscopy. The Mössbauer spectra of all samples were analysed using a Normos package. The low field magnetic characteristics, i.e. magnetic permeability, maximum induction, and core losses were carried out for ribbons by a transformer method using a completely automated setup. The results obtained from magnetic measurements were used for calculation of basic parameters of a transformer with the help of RALE software.

\section{Results and discussion}

Room temperature X-ray diffraction patterns and Mössbauer spectra of the $\mathrm{Fe}_{82} \mathrm{Zr}_{4} \mathrm{Nb}_{3} \mathrm{~B}_{10} \mathrm{Cu}_{1}$, $\mathrm{Fe}_{80} \mathrm{Zr}_{4} \mathrm{Mn}_{3} \mathrm{~B}_{12} \mathrm{Cu}_{1}$, and $\mathrm{Fe}_{80} \mathrm{Zr}_{4} \mathrm{Ti}_{3} \mathrm{Cu}_{1} \mathrm{~B}_{12}$ alloys in Fig. 1 showed that only sample containing $\mathrm{Ti}$ was amorphous in the as-quenched state whereas the as-quenched Nb- and Mn-containing sample were partially crystalline (about $25 \%$ of the crystalline phase). The Mössbauer spectrum of the $\mathrm{Fe}_{80} \mathrm{Zr}_{4} \mathrm{Ti}_{3} \mathrm{Cu}_{1} \mathrm{~B}_{12}$ alloy in Fig. 1c displays a broad structure characteristic of an amorphous ferromagnet. After annealing at $725 \mathrm{~K}$ for $1 \mathrm{~h}$ the amount of the crystalline phase in $\mathrm{Fe}_{80} \mathrm{Zr}_{4} \mathrm{Ti}_{3} \mathrm{Cu}_{1} \mathrm{~B}_{12}$ was comparable to that of the Nanoperm-type as-quenched alloys containing $\mathrm{Nb}$ and $\mathrm{Mn}$ atoms. Further annealing of the $\mathrm{Fe}_{82} \mathrm{Zr}_{4} \mathrm{Nb}_{3} \mathrm{~B}_{10} \mathrm{Cu}_{1}$, $\mathrm{Fe}_{80} \mathrm{Zr}_{4} \mathrm{Mn}_{3} \mathrm{~B}_{12} \mathrm{Cu}_{1}$, and $\mathrm{Fe}_{80} \mathrm{Zr}_{4} \mathrm{Ti}_{3} \mathrm{Cu}_{1} \mathrm{~B}_{12}$ alloys at $673 \mathrm{~K}$ for $0.5 \mathrm{~h}, 773 \mathrm{~K}$ for $0.5 \mathrm{~h}$ and $773 \mathrm{~K}$ for $1 \mathrm{~h}$, respectively, leads to creation of about $50 \%$ of $\alpha$-Fe crystalline phase. All Mössbauer spectra in Fig. 2 consist of broad, overlapped lines assigned to disordered 
amorphous matrix and sharp narrow lines confirming a presence of bcc Fe crystals.

TABLE I

Basic transformer parameters.

\begin{tabular}{l|c}
\hline \hline Volt-ampere rating, $S$ & $50 \mathrm{~V} \mathrm{~A}$ \\
\hline frequency, $f$ & $1 \mathrm{kHz}$ \\
input voltage, $U_{1}$ & $250 \mathrm{~V}$ \\
output voltage, $U_{2}$ & $26 \mathrm{~V}$ \\
output current, $I_{2}$ & $2 \mathrm{~A}$ \\
current density, $J$ & $\approx 3.5 \mathrm{~A} \mathrm{~mm}^{-2}$ \\
flux density, $B$ & $0.5 \mathrm{~T}$
\end{tabular}

Magnetic properties of $\mathrm{Fe}-\mathrm{Zr}-\mathrm{B}-\mathrm{Cu}$ alloys strongly depend on their microstructure [3]. All investigated samples show rather poor soft magnetic prop- erties in the as-quenched state. The annealing of the $\mathrm{Fe}_{82} \mathrm{Zr}_{4} \mathrm{Nb}_{3} \mathrm{~B}_{10} \mathrm{Cu}_{1}, \mathrm{Fe}_{80} \mathrm{Zr}_{4} \mathrm{Mn}_{3} \mathrm{~B}_{12} \mathrm{Cu}_{1}$, and $\mathrm{Fe}_{80} \mathrm{Zr}_{4} \mathrm{Ti}_{3} \mathrm{Cu}_{1} \mathrm{~B}_{12}$ alloys improves their magnetic properties and frequency characteristics for all investigated samples. The as-quenched $\mathrm{Mn}$ - and Ti-containing ribbons exhibit the saturation magnetic flux density $\left(B_{\mathrm{S}}\right)$ of about $1.0 \mathrm{~T}$ whereas $B_{\mathrm{S}}$ for the as-quenched $\mathrm{Fe}_{82} \mathrm{Zr}_{4} \mathrm{Nb}_{3} \mathrm{~B}_{10} \mathrm{Cu}_{1}$ ribbon is equal to $1.3 \mathrm{~T}$. An increase of the crystalline phase up to about $50 \%$ leads to growth of $B_{\mathrm{s}}$ to values of $1.6 \mathrm{~T}, 1.4 \mathrm{~T}$, and $1.3 \mathrm{~T}$ for the samples containing $\mathrm{Mn}, \mathrm{Ti}$, and $\mathrm{Nb}$, respectively. It is worth noticing that the $\mathrm{Fe}_{80} \mathrm{Zr}_{4} \mathrm{Ti}_{3} \mathrm{Cu}_{1} \mathrm{~B}_{12}$ alloy shows better characteristics of core losses vs. frequency in comparison with the $\mathrm{Fe}_{82} \mathrm{Zr}_{4} \mathrm{Nb}_{3} \mathrm{~B}_{10} \mathrm{Cu}_{1}$ and $\mathrm{Fe}_{80} \mathrm{Zr}_{4} \mathrm{Mn}_{3} \mathrm{~B}_{12} \mathrm{Cu}_{1}$ alloys.

Transformer parameters obtained by simulation $\left(B_{\max }=0.5 \mathrm{~T}\right.$ and $\left.f=1 \mathrm{kHz}\right)$.

TABLE II

\begin{tabular}{|c|c|c|c|c|c|}
\hline Material composition & Annealing condition & $\begin{array}{c}\text { Core weight } \\
{[\mathrm{kg}]}\end{array}$ & $\begin{array}{c}\text { Core losses } \\
{[\mathrm{W}]}\end{array}$ & $\begin{array}{c}\text { Total losses } \\
{[\mathrm{W}]}\end{array}$ & $\begin{array}{c}\text { Efficiency } \\
{[\%]}\end{array}$ \\
\hline \multirow{2}{*}{$\mathrm{Fe}_{82} \mathrm{Zr}_{4} \mathrm{Nb}_{3} \mathrm{~B}_{10} \mathrm{Cu}_{1}$} & $\begin{array}{c}\text { as-quenched } \\
\text { (nanocrystalline) }\end{array}$ & 0.145 & 0.29 & 2.02 & 95.88 \\
\hline & $\begin{array}{c}673 \mathrm{~K} / 0.5 \mathrm{~h} \\
\text { (nanocrystalline) }\end{array}$ & 0.145 & 0.17 & 1.87 & 96.16 \\
\hline \multirow{2}{*}{$\mathrm{Fe}_{80} \mathrm{Zr}_{4} \mathrm{Mn}_{3} \mathrm{~B}_{12} \mathrm{Cu}_{1}$} & $\begin{array}{c}\text { as-quenched } \\
\text { (nanocrystalline) }\end{array}$ & 0.145 & 0.24 & 1.96 & 96.00 \\
\hline & $\begin{array}{c}773 \mathrm{~K} / 0.5 \mathrm{~h} \\
\text { (nanocrystalline) }\end{array}$ & 0.145 & 0.11 & 1.80 & 96.30 \\
\hline \multirow{3}{*}{$\mathrm{Fe}_{80} \mathrm{Zr}_{4} \mathrm{Ti}_{3} \mathrm{Cu}_{1} \mathrm{~B}_{12}$} & $\begin{array}{l}\text { as-quenched } \\
\text { (amorphous) }\end{array}$ & 0.145 & 0.14 & 1.84 & 96.24 \\
\hline & $\begin{array}{c}723 \mathrm{~K} / 1 \mathrm{~h} \\
\text { (nanocrystalline) }\end{array}$ & 0.145 & 0.14 & 1.84 & 96.23 \\
\hline & $\begin{array}{c}773 \mathrm{~K} / 1 \mathrm{~h} \\
\text { (nanocrystalline) }\end{array}$ & 0.145 & 0.07 & 1.76 & 96.40 \\
\hline $\mathrm{Fe}_{73} \mathrm{Cu}_{1} \mathrm{Nb}_{3} \mathrm{Si}_{13} \mathrm{~B}_{10}$ & $\begin{array}{c}\text { optimal annealing } \\
\text { (nanocrystalline) }\end{array}$ & 0.145 & 0.13 & 1.83 & 96.25 \\
\hline $\mathrm{Fe}-3.2 \% \mathrm{Si}$ & $\begin{array}{c}- \\
\text { crystalline }\end{array}$ & 0.162 & 1.73 & 3.44 & 93.21 \\
\hline
\end{tabular}

Based on the results and characteristics obtained for the $\mathrm{Fe}_{82} \mathrm{Zr}_{4} \mathrm{Nb}_{3} \mathrm{~B}_{10} \mathrm{Cu}_{1}, \mathrm{Fe}_{80} \mathrm{Zr}_{4} \mathrm{Mn}_{3} \mathrm{~B}_{12} \mathrm{Cu}_{1}$, and $\mathrm{Fe}_{80} \mathrm{Zr}_{4} \mathrm{Ti}_{3} \mathrm{Cu}_{1} \mathrm{~B}_{12}$ alloys (Fig. 3), we have performed simulation of parameters of magnetic cores in a flyback transformer with the help of RALE software. All simulations of parameters for toroidal cores were performed for partially crystallized samples with about $25 \%$ and $50 \%$ crystalline phase fraction. The basic transformer parameters and results of simulations obtained for $B_{\max }=0.5 \mathrm{~T}$ and $f=1 \mathrm{kHz}$ are presented in Table I and Table II, respectively.
Finemet and $\mathrm{Fe}-3.2 \% \mathrm{Si}$ polycrystalline alloy are included in Table II as well. From this table it is seen that the flyback transformer made from a nanocrystalline $\mathrm{Fe}_{80} \mathrm{Zr}_{4} \mathrm{Ti}_{3} \mathrm{Cu}_{1} \mathrm{~B}_{12}$ alloy obtained by annealing of the amorphous ribbons at $773 \mathrm{~K}$ for $1 \mathrm{~h}$ shows the lowest core losses and the highest efficiency. Its parameters are better than those for the transformer with the core made from Finemet $\mathrm{Fe}_{73} \mathrm{Cu}_{1} \mathrm{Nb}_{3} \mathrm{Si}_{13} \mathrm{~B}_{10}$ alloy subjected to optimal annealing and from polycrystalline $\mathrm{Fe}-3.2 \% \mathrm{Si}$ alloy. 


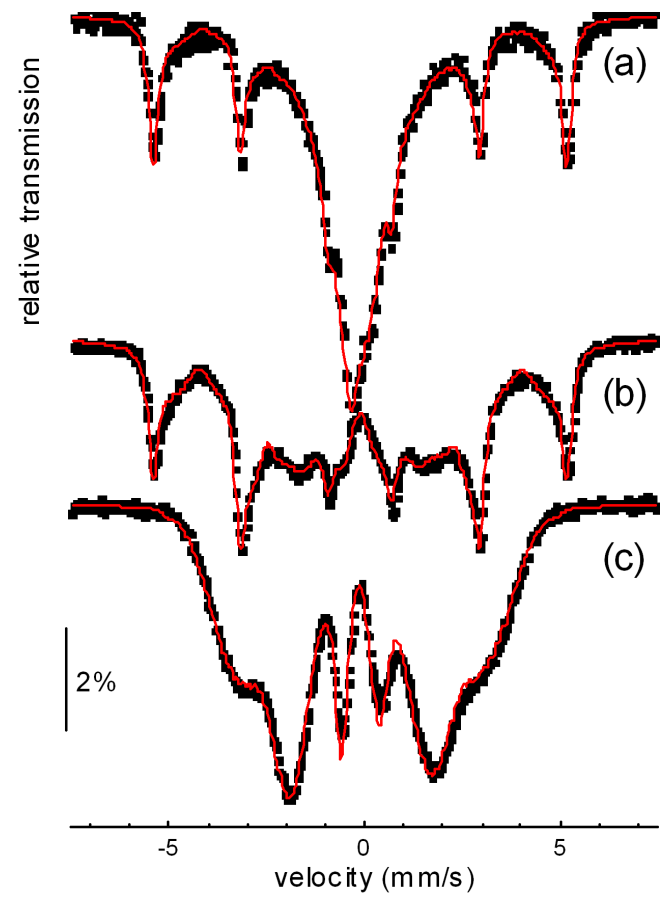

Fig. 1. ${ }^{57} \mathrm{Fe}$ transmission Mössbauer spectra of as-quenched $\mathrm{Fe}_{82} \mathrm{Zr}_{4} \mathrm{Nb}_{3} \mathrm{~B}_{10} \mathrm{Cu}_{1} \quad(a)$, $\mathrm{Fe}_{80} \mathrm{Zr}_{4} \mathrm{Mn}_{3} \mathrm{~B}_{12} \mathrm{Cu}_{1}(b)$, and $\mathrm{Fe}_{80} \mathrm{Zr}_{4} \mathrm{Ti}_{3} \mathrm{Cu}_{1} \mathrm{~B}_{12}$ (c) alloys.

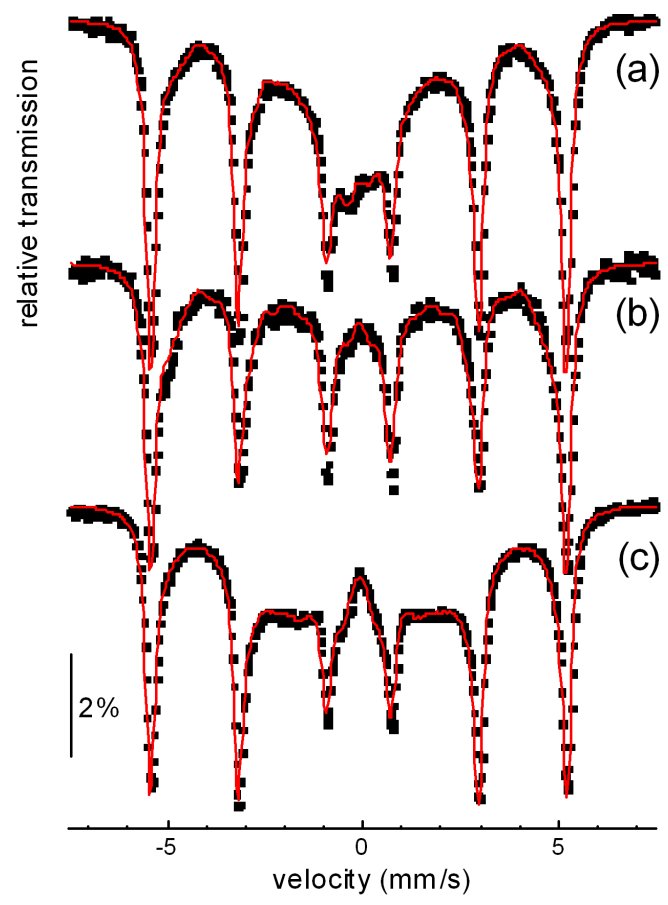

Fig. 2. ${ }^{57} \mathrm{Fe}$ transmission Mössbauer spectra of annealed $\mathrm{Fe}_{82} \mathrm{Zr}_{4} \mathrm{Nb}_{3} \mathrm{~B}_{10} \mathrm{Cu}_{1}(a), \mathrm{Fe}_{80} \mathrm{Zr}_{4} \mathrm{Mn}_{3} \mathrm{~B}_{12} \mathrm{Cu}_{1}(b)$, and $\mathrm{Fe}_{80} \mathrm{Zr}_{4} \mathrm{Ti}_{3} \mathrm{Cu}_{1} \mathrm{~B}_{12}(c)$ alloys.

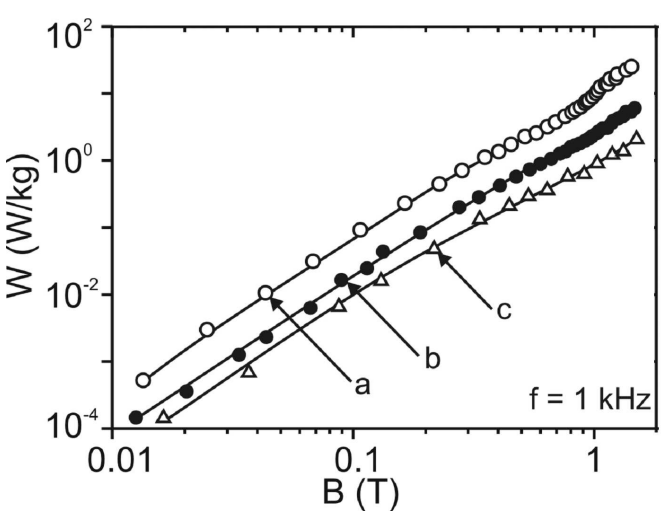

Fig. 3. Relation between core losses and induction at frequency of $f=1 \mathrm{kHz}$ for nanocrystalline $\mathrm{Fe}_{82} \mathrm{Zr}_{4} \mathrm{Nb}_{3} \mathrm{~B}_{10} \mathrm{Cu}_{1}(a), \mathrm{Fe}_{80} \mathrm{Zr}_{4} \mathrm{Mn}_{3} \mathrm{~B}_{12} \mathrm{Cu}_{1}(b)$, and $\mathrm{Fe}_{80} \mathrm{Zr}_{4} \mathrm{Ti}_{3} \mathrm{Cu}_{1} \mathrm{~B}_{12}$ (c) alloys with about $50 \%$ of crystalline phase.

\section{Conclusion}

In conclusion, heat treatment of the $\mathrm{Fe}_{80} \mathrm{Zr}_{4} \mathrm{Ti}_{3} \mathrm{Cu}_{1} \mathrm{~B}_{12}$ alloy at $773 \mathrm{~K}$ for $1 \mathrm{~h}$ produces nanocrystalline alloys with proper microstructure and excellent soft magnetic properties for a design of low power transformers. $\mathrm{Fe}_{82} \mathrm{Zr}_{4} \mathrm{Nb}_{3} \mathrm{~B}_{10} \mathrm{Cu}_{1}, \mathrm{Fe}_{80} \mathrm{Zr}_{4} \mathrm{Mn}_{3} \mathrm{~B}_{12} \mathrm{Cu}_{1}$, and $\mathrm{Fe}_{80} \mathrm{Zr}_{4} \mathrm{Ti}_{3} \mathrm{Cu}_{1} \mathrm{~B}_{12}$ nanocrystalline alloys show better efficiency and core losses than classical transformers with cores made from polycrystalline $\mathrm{Fe}-3.2 \% \mathrm{Si}$ alloy.

\section{Acknowledgments}

This work was partially supported by the grants SK-PL-0013-09, VEGA 1/0033/10, and MSM6198959218.

\section{References}

[1] A. Makino, T. Bitoh, A. Inoue, T. Masumoto, J. Appl. Phys. 81, 2736 (1997).

[2] M. Müller, H. Grahl, N. Mattern, U. Kühn, Mater. Sci. Eng. A 226-228, 565 (1997).

[3] A. Makino, T. Hatanai, Y. Naitoh, T. Bitoh, IEEE Trans. Magn. 33, 3793 (1997). 